\title{
応 用 報 告
}

\section{化學エ業におけるアルミニウム}

小林藤 次 郎*

\section{ALUMINIUM IN GHEMICAL INDUSTRY}

TOJIRO KOBAYASHI*

\section{1. ま えがき}

アルミニウムとその合金が、今日世界各国において化 学工業や食品工業の諸設備、機器、部品等に広範囲にわ たつて使用されていることはすでによく知られた事柄で あるが、わが国でも昨年 (1954年) に全需要 73,409 能の 約0.9\% (693旡) がこの方面に使用されている。

このようにアルミニウムが、わが国の化学工業方面に 利用されて来た今日までの歷史を発生的に調べることは 興味のあることで、なかなか困難な仕事である。それは なにをもつてそのこう矢とするか簡単には証明出来ない からである。後で述べるようにわが国では、日本アルミ ニユーム製造所(現在の日本アルミニウム工業株式会社) で昭和の初め頃から少しつうこの方面の製品を造り、昭 和 8 年以降に種々の化学用製品を相当沢山製造したが、 同样の記録が国内の外にあるかも知れないし、無いとい う確認もできないので、本文では化学工業用品の材料に アルミニウムを使用した初期の実例を日本アルミニユー 厶製造所において取扱つたものを通して説明する。

化学薬品に対するアルミニウムの腐食やその耐食性に ついての諸外国の研究は1913年（大正 3 年）以降の諸雑 誌に活発な発表がみられることからアルミニウムをこの 方面に利用する企図が行なわれようとしていたことが類 推される。日本のその頃にはまだ、文献も認められな い。しかし1930年頃には第 1 表1)に示した記録にあるよ うにすでに化学工業用として相当量のアルミニウムが実 際に使用されていたことがわかる。この頃の米国と独国 の記録を第 2 表 $\left.{ }^{2}\right)$ と第 3 浸 3 に示したがやはり相当量が 使われ、この頃ではもう実用化への軌道に乗つている観 がある。

しかし今日のようにアルミニウムの製鍊、材料あるい は加工会社が持つているアルミニウムに関する化学工業 方面への具体的知識や豊富な経験は昭和の初期にはほ上 んど持つていなかつたと思われる。したがつてアルミニ
ウムの加工会社が、例えば硝酸タンクのような設備を受 註するのに積極的に耐食性や軽量化からその実用性を需

第1表 1930年代における日本のアルミニウム 用途別消費量

単位 $=\%$

\begin{tabular}{|c|c|c|c|c|}
\hline 次 & $\begin{array}{c}1930 \\
(\text { 昭. } 5)\end{array}$ & $\begin{array}{c}1931 \\
(\text { 昭.6) }\end{array}$ & $\begin{array}{c}1934 \\
(\text { 昭. } 9)\end{array}$ & $\begin{array}{c}1935 \\
(\text { 昭. 10) } \\
\end{array}$ \\
\hline 器 & 50.0 & 55.0 & 56.3 & 56.3 \\
\hline 電 & 26.6 & 14.0 & 3.6 & - \\
\hline 軍 & 10.0 & 12.0 & 20.0 & 20.0 \\
\hline 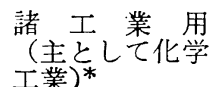 & 9.0 & 11.0 & 13.0 & 12.0 \\
\hline そ李他 製 鋼 & - & 8.0 & 3.2 & $5.6 \Delta$ \\
\hline 八 & 4.4 & - & 2.3 & $2.5 \Delta$ \\
\hline 粉 & - & - & 2.1 & $2.8 \Delta$ \\
\hline 雑 & - & - & $\ldots$ & 0.8 \\
\hline 合 計 \% & 100 & 100 & 100 & 100 \\
\hline 総重 量 (酩) & 8,684 & 10,242 & 2,100 & 12,487 \\
\hline
\end{tabular}

註 *主として化学工業用とあるも内容不詳

、輸出品が含まれている

第 2 表 米国における用途 別消費量(1930)

\begin{tabular}{|c|c|}
\hline 用 途 名 & 比率(\%) \\
\hline 自動車 - 航空機 & 38 \\
\hline 電 & 16 \\
\hline 食 & 14 \\
\hline 製 鋼 用 & 8 \\
\hline 建 & 4 \\
\hline 一般鋳造用 & 2 \\
\hline 化 学 工 業 & 1 \\
\hline そ の 他 & 4 \\
\hline 合 & 100 \\
\hline 総 重 量 (䣩) & 95,000 \\
\hline
\end{tabular}

第 3 表 ドイッにおける用 途別消費量(1931)

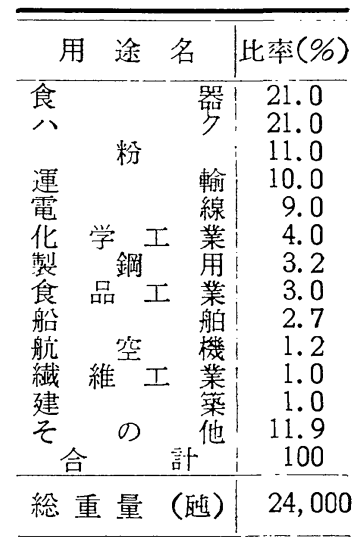


要家に強調したことは考えられない。筆者の調べた範囲 では当時この種のアルミニウム製品の製造はすべて需要 家（化学工業側）からの指示によつて行われている。す なわち材質を指定した図面が与えられるか、既設の装置 のスケッチによつて会社はその指示通り行つていたよう で、ただはつきり言えることはこの種の加工に必要な酸 素一アセチレンによるガス熔接がこの頃現場でも日常茶 飯事として立派に行われていたことである。アルミニウ ムのガス熔接に必要なフラックスは昭和の初めから輸入 されていた。フランス製のハラキリ粉がそれで、非常に 優秀な性能をもつており当社でも始めこれを使用し、昭 和10年前後にはこれに似たものを社内で製造している。 しかしここで不思議と思われることは需要家が何故アル ミニウムを率先して指定したかということで、これは次 の理由で容易に諳解できた。例えば硝酸は昭和12年の国 内生産量が約 10 万䂐で、これはその 5 年前の昭和 7 年の 生産量の約倍である。4すなわちこの頃は旧来のチリ硝 石からの製造法が空中窒素固定法による、いわゆる合成 法に代わり、その結果として生産が日增しに活発化して いた時代だから、外国から導入した生産設備の新設、改 廃あるいは增筑などに購入時附随していた図面や現物の スケツチ等を基礎として当社に註文を出した。そして純 度の不明な材種は会社や京都大学で分析していた。この 頃の材質はほとんど軟質材が使われていたようで就強を 鋼材で行うことにすれば軟貎材でリベツト締めと、熔接 技術があ机ば、一応図示の通りものが出来たわけだが、 納入後の経過をメーカーとして随分心配したことだろう と想像される。しかしそれが需要家に満足な成果を与え 次の註文を引受けるようになると、前の経験が役に立ち 自信もできて遂次継続することによつて次第に経験を積 み重ねて来た。これが当時の実情だと思われる。異種金 属との接触腐食のようなことは考えも及ばず褋のままで 接触していたとしても当時の常識では別に不見識でなか つたであろう。当時使用したアルミニウム地金の純度は 99.8\%以上のもので、米国のアルコアや英国のノーザン アルミニウム会社から輸入し、これを板に圧延した。大 型のものには $4^{\prime} \times 8^{\prime}$ の板を熔接している。タンク類の多 くはこうした板を熔接して造つている。

さて今日広く行われている腐食試験は腐食液中に試料 を㳗清し、その重量减や機械的性質、特に引張強さと伸 びの減少を測定する方法で 1926 年（昭和元年）F. N. Speller により提出されたものだが5)、侵食が均一ない わゆる均食の場合は重量隇と強度隇が平行するという実 験的事実にもとづいたものである。

例えばボーメ $42^{\circ}$ の硝酸に対する或る純湾のアルミニ ウムの重量減を実験的に確かめ、これから計算した平均 侵食度が 1 力年 $0.015 \% / m$ とし、この硝酸を入れるドラム
の板厚が強度計算から $4.2 \mathrm{~m} / \mathrm{m}$ を必要とするならば、この ドラムに 5 カ年間の使用寿命を与えるに必要な最初の板 覃を $4.2+0.015 \times 5=4.275 \%$ と計算し、少くとも板厚を $4.3 \frac{m}{m}$ とすることによつて純硝酸を 5 力年間安全に取扱 うことが出来るとしている。同様な計算はアルミニウム の各種容器に対しても行われ、もし侵食の形式が孔食性 の場合は 1 力年間の孔食の最大深さを知ることによつて 同じように算出することが出来る。

今日アルミニウムが化学工業や食品化学工業に多く利 用される理由として次の諸点があげられるが、この場合 その機械的性質よりも河食性が優先的に考虙されねばな らない。

1）化学作用に抵抗する (臫食性) アルミニウムやそ の合金の耐食性はこの材料の表面が常に保有しているア ルミニウム酸化物の薄い朕によつて年えられる。しかし この酸化膜は比較的容易に機械的察過により破壤さ扎る が、直ちに再生し、これが多くの化学薬品の侵食に対し て母材を保護するといわ机る。したがつてこの酸化膜を 侵すような化学薬品には全然耐食性を示さない。濃硝酸 にアルミニウムが耐食的であるといらのもしょせんは酸 化生成物の被膜によるためとしている。アルマイトその 他人為的表面被膜を与える種々の才法が実用されている のも主としてその耐食性をより十分にするためである。

2）反応によつて生じたアルミニウム化合物が製品の 外観を損じないし、それが無毒で、しかも酸化しない特 性と生理学的に不活発であるため食品化学方面の器具や 容器の材料に好んで使用されることになるのも当然であ る。

3）熱の伝導度は $20^{\circ} \mathrm{C}$ でアルミニウムは 0.52 (cal) $\mathrm{cm}^{2} / \mathrm{cm} /{ }^{\circ} \mathrm{C} / \mathrm{sec}$ ) 軟鋼は0.12、銅が0.93だから、軟鋼の 4 〜 倍あり、銅の約环で、ステンレスのように耐食性 が極めて良好でも熱の伝導度が0.03では熱交換器などの 熱の授受を目的とするものの材料には不適当である。

この点アルミニウムは熱の伝導、熱の分配又は正確な 温度調節の目的に、その耐食性と共に適した材料といわ れている。

4）高い反射率がある。アルミニウムはその表面の状 況によるが、白色光線の 75 ～85\%のの射率を示し、特に アルミニウムハクは熱の絶縁物として広く使われてい る。

5）軽量である。アルミニウムが鋼忉やステンレスあ るいはニツケル等の貫金属の約1/3の此重であることは良 く知られているが、これが化学工業面においても各種設 備の重量軽減となり、器具や装置の取扱いを容易にし、 また化学製品の運搬等の場合その容器（風华) の軽量化 に役立つために軽視できない。

6）設訃、構造が簡易化される。アルミニウムの特性 
といわれる各種の複雑な断面をもつ押出形材が利用でき るから鋼材を使用する場合に較べて、遥かに設訃が楽で 構造が簡易化できる。

7）加工が容易である。板金加工としての折曲ゲ、フ ランジ出し、庄控や熔峐、ロウ接などができるので、あ らゆる形状に加工され、しかもバフ研磨、ブラシ目、サ ンドブラストをはじめ化学的あるいは電気化学的に表面 処理が容易に行われ、いろいろの表面状態を与えること ができるのもこの方面の需要が多い原因の一つである。 もちろん今日では良好な塗料が造られ、強い塗膜をもつ た塗装もできる。

8）廃材が高価である。鋼材とちがいアルミニウム製 の装置や器具の廃品はその純度に応じて高洒に取引きさ れるので、新規購入時の若干のコスト高もこれによつて 割安になる。

9）ステンレススティールに較べて材料費が相当低廉 となるので、現在ではステンレスに代つてアルミニウム が広範囲に化学工業面に進出している。

化学薬品に対するアルミニウムやその合金の一般的举 動については次のようなことがいわれる。まず表面の酸 化膜が侵されない限り腐食に対して懸念なく、 $\mathrm{pH}$ 5 8 程度の溶液ではあまり問題とならない。そして酸性とか アルカリ性というょりもその中に存在するイオンの種類 によつて耐食性が左右される。八ロゲン族は硝酸塩や硫 酸塩より侵食的で、また重金属の銅、鉛、コバルト、ニ ツケル等はアルミニウムに対して耐食的に有害である。 有機物についても不適当なものが幾つかある。温度の影 響は他の金属と同様温度上昇にともない侵食的で、アル ミニウム側からみ机は耐食性が低下することになる。ま たアルミニウムの純度や合金の添加元素にも大きくその 耐食性が左右されることはもちろんである。各化学薬品 についての適否は後の各論に挙げる。

\section{参考文 献}

1）田辺、現代工業用アルミニウム合金の展望 ア ルミニウム総覽(昭. 12)p. 229 金物時代社

2) Andre Hug. Die Wirtschaftliche Bedeutung des Aluminium 1934

3) Alcoa 社調查

4）矢野、白崎日本国勢図会 昭. 16, p. 352 国勢社.

5) F. N. Speller Corrosion 1926, p. 203 McGraw$\mathrm{Hill}$

\section{2. 戦前の製品}

当社は明治34年以来アルミニウム製器物の製造をもつ ぱら行つていたが、アルミニウムを利用する範囲が次第 に広まるに伴い、板金物といわれる種々の工業用品の製 造を始めた。しかしこのような仕事は昭和年代に入つて
から昭和14〜15年の戦時への切替えとその後の䅂戦の始 末で当侍の図面や記録を全部失つているため、真相は当 時これ等の製作に従事し、今な打健在な人々の記憶によ る外ない。しかもその記憶がはつきりせずここうであつ たろうミという程度のものが多いので本項では出来るだ けはつきりしたものだけをまとめた。幸い数枚の写真が 残つているので、それを紹介するが、重要な諸点の欠け ていることは止むを得ない。それに現在でもそうである が、当時も化学工業や化繊関係では製作に必要なこと以 外一切を秘密にし、製作する側でも良く心得て不要な質 問をしないため、極端な場合は何に使うかわからないも のがしばしばあつたとのことである。ここでは当時の繁 品を一応並べるに止め、具体的なことは後に述べる戦後 の製品について挙げる。

最も古いものでは、昭和 2 年塩野義製薬会礼に納入し たアスピリンの板状絬晶を作るための輸送管、貯蔵榑、 脱水装置等を純度 $99.5 \%$ のアルミニウムで作つたが、そ の形態やその後の状況については何の記録もない。この 年塗料会社の註文でワニスを加熱する鉒を純度 $99.0 \%$ 、 板厚 $6 \mathrm{~m} / \mathrm{m}$ 板で直径 3 尺、深さ 4.5 尺のものを作つてい る。また昭和 6 年に日本酒（菊正）の醇造用貯蔵槽とし て、直径 7 尺、高さ 7 尺のタンフを純度 $99.5 \%$ 、厚さ 4 m/mのアルミニウム板を熔接で造つているが、これはその 後失敗に終つたとのことである。後で述べるが、この種 のものに何等表面処理をしないアルミニウムを使用する と十数日後に水酸化アルミニウムの沈澱が発生し、觜好 品としての酒の外観を損じるから実用できない。アルミ ニウムがアルコールに侵されないということから日本酒 に利用したわけだが、酒の中の防腐剂にアルミニウムが 侵されることを確かめなかつた失敗であつた。今日では この種のものに使用するアルミニウムには化学処理や電 気化学処理による表面処理によつて、防食できることが 明かにされている。

硝酸工業一昭和 8 年から12年にわたつてここに挙げた ものやその他各種容量のものを製造した。Photo.1は住 友化学（新居浜）に納入（昭和 9 年）した容量10トンの 濃硝酸用タンクで純度 $99.8 \%$ 、板厚は 4 mmである。同じも の6基を造つている。この年にはまた Photo. 2 のように 鉄板に純度 $99.8 \%$ のアルミニウム板をライニングした直 径 $3,500 \mathrm{~m} / \mathrm{m}$ 、高さ $3,500 \mathrm{~m} / \mathrm{m}$ の容量30トンの濃硝酸タンクを 造つた。外側の鉄板 $(1 / 4 / m / m$ 厚 $)$ と内側のアルミニウム ( $4 \mathrm{~m} / \mathrm{m}$ 厚) との締結はその是非は別として Fig. 1 の上う に鉄鋲で締め、鋲尻の露出部分はアルミニウムの帯でカ バーし、その両縁をライニングのアルミニウムに熔接し て、鉄鋲をかくしているという方法がとられている。タ ソク内面にビードのように巻いてある条帯がそれ:であ る。もちろん当時のこととて、接触腐食については何等 


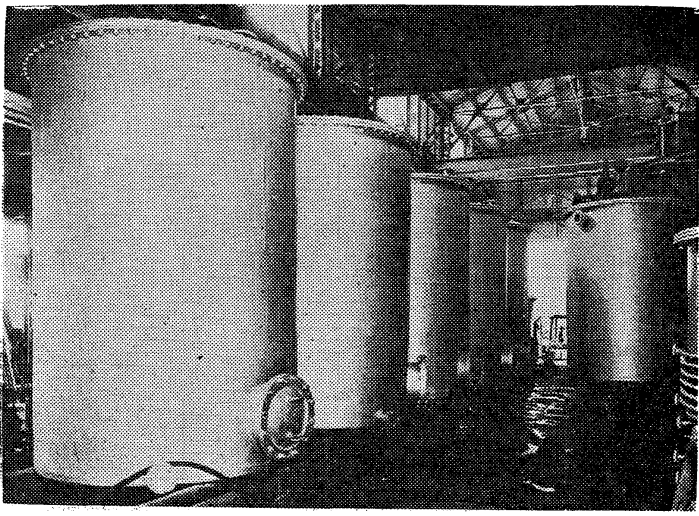

Photo. $110 \mathrm{~kg}$ 硝酸タンク

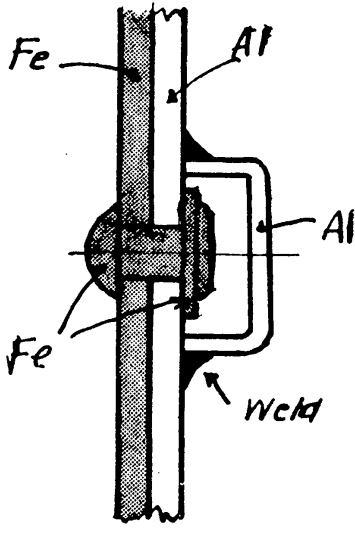

Fig. 1 Al板と鉄板の締結
年に R. Seligman と P. Williams の研究が あり、昭和 5 年にはま た1923年の W. Calcott と J. Whetzel の実験 絬果と、硝酸タンクに 使用した実例が、Edー ward 等によつてChemical Engineering

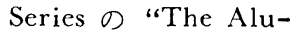
minium Industry" (1930, McGraw-Hill) に掲載、紹介された。

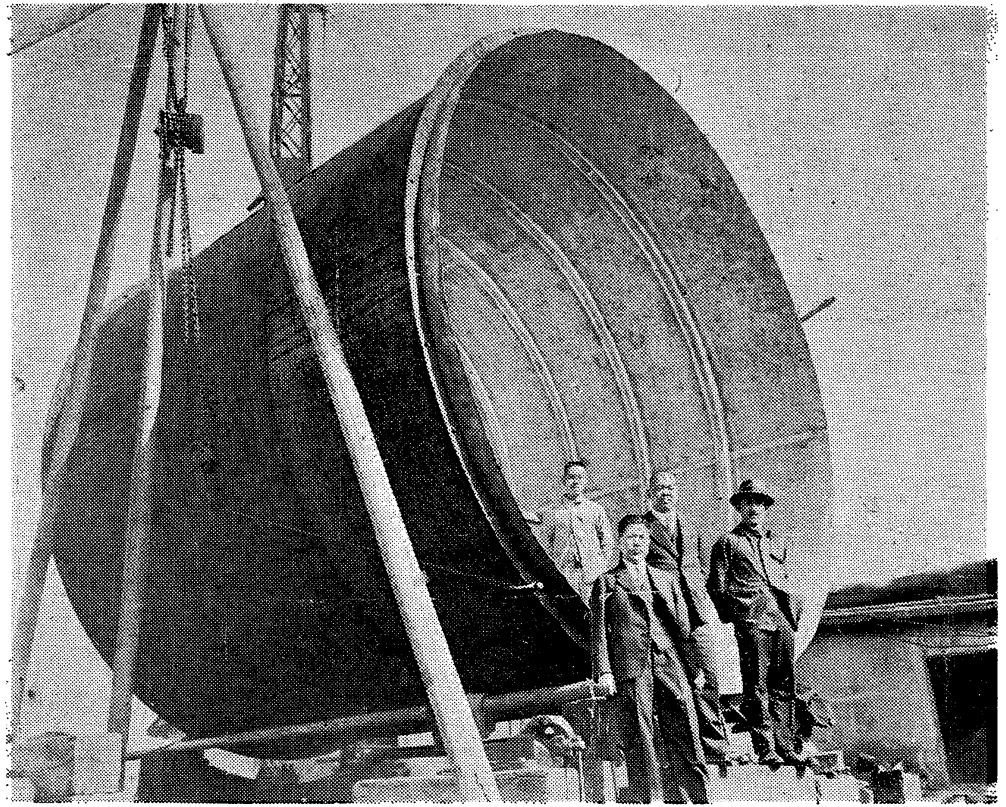

Photo. $230 \mathrm{~kg}$ 硝酸タンク、鉄板にアルミニウムがライニングしてある

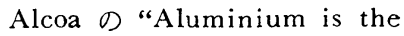
Chemical Indusrty" (1935) や 小久保博士の ॥アルミニウムの 性質とその用途、等の著書如少 し遅れて発行され、同じく濃硝 酸に対する実用性を紹介されて いる。たたこのようなことが、 現場技術者や営業面にどの程度 利用されていたかは明かでな い。

ビールエ業一昭和 10 年キリン ビールにPhoto. 6のような焐母: を貯える容器(ヘイヘイワンネ) を納入している。板の純度は $99.5 \%$ 、板厚 $3 \mathrm{~m} / \mathrm{m}$ のアルミニウ ム板から䟠部と上部をそれぞれ 別に造り、これを胴まわりで熔 按し 1 体としてこの形状に㠲出

してある。回転卙が入る鋼製の 考䈍が払われてない。この翌年 Photo. 3に示した100卜 ン濃硝酸タンクを同じ純度で板厚 $6 \mathrm{~m} / \mathrm{m}$ をやり鉄板にラ イニングして造つた。これは $\phi 5,000 \times 5,100 \mathrm{~m} / \mathrm{m}$ 大きささ で、当時としては形態の非常に大きいものとして相当話 題をまいた。このような大型では、当時の工場建屋内は もちろん、建屋外でも行えないため輸送も考虑して舟運 に便利な現在の日立造船、当時の大阪鉄工所桜島工場の 敷地を借りて組立てた。また Photo. 4.のような船積用の 濃硝酸タンヤや、Photo. 5 の硝酸製造用オートクレーブ 支 $99.8 \%$ 、板厚10〜 $12 \mathrm{~m} / \mathrm{m}$ のアルミニウム板から製造（昭 和11年)している。とにかくこの頃は大型物といえばほと んど硝酸用のものであつた。

このように硝酸に対するアルミニウムは、今から約20 年以前から実用されていて、戦後の新用途ではない。こ れを裏付けするアルミニウムの耐食性については、1917 ソケツトは本体にアルミニウム鋲で取付けられ、内面に 出た鋲尼は，本体に熔接してこの部分を滑かに仕上げてい る。フチ巻きは心に1 吋のガス管を包んで補強し、台枠 は鋼材でアルミニウムペイントを塗つてある。この種の ものは洗滌時に雑菌が残らぬようにするため、内表面は 極めて嚴重な滑らかさを要求された。僅かの傷があつて もいけないということで、ビールに限らず牧やその他 豆腐類に至るまで、この種の容器を造る時には表面傷は もちろん、洗滌が楽にできるよう設計することが必要と された。

熱交換器一昭和12年某化成会社向に Photo. 7 の上う な熱交換器を製造した。純度99.8\%で、チユーブプレー トの厚さ50 m/m以外詳しいことは不明だが、傍に立つ大人 の身長からその大きさが推定できる。また染色用コンデ ンサーとして Photo. 8 のようなものを造つているが、 

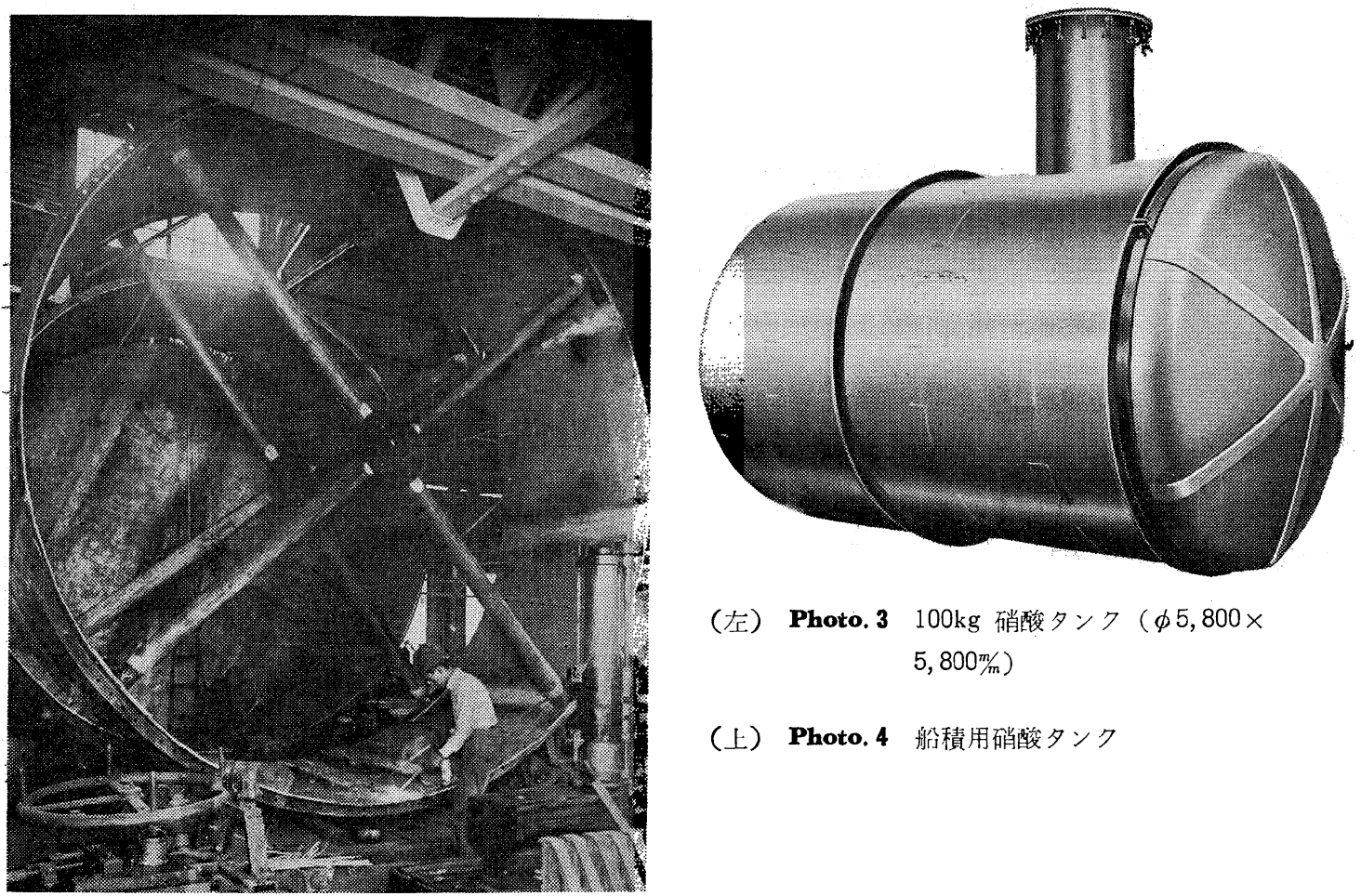

（左）Photo. $3100 \mathrm{~kg}$ 硝酸タンク（ $\phi 5,800 \times$ $5,800 \mathrm{~m} / \mathrm{m})$

（上） Photo. 4 船積用硝酸タンク

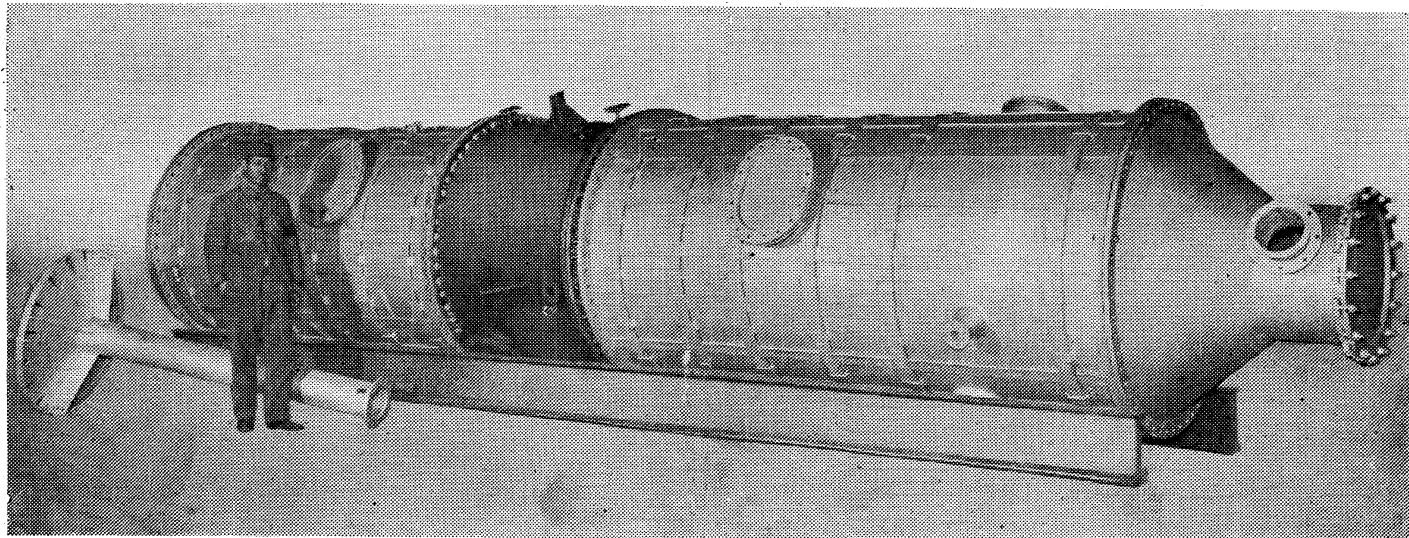

Photo. 5 硝 酸用オ

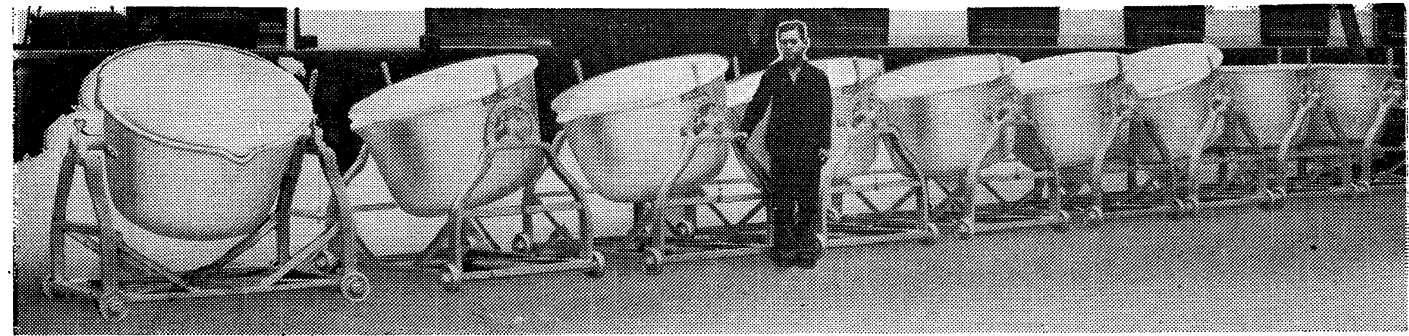

Photo. 6 ビール用酵母容器（ヘイヘイワンネ）

詳細は明かでない。この種の㠜縮器、冷却器は䋡横種々 の型式のものを数多く造つていた。

バルブ類一当特は板金製品のみでなく、アルミニウム
の鋳物製品も化学工業向けに種々造つた。ここに示した Photo. 9 はアンモニアガスや硝酸用として99.8\%の純ア ルミニウムで鋳造した仕切畣であるが、この外種々のバ 


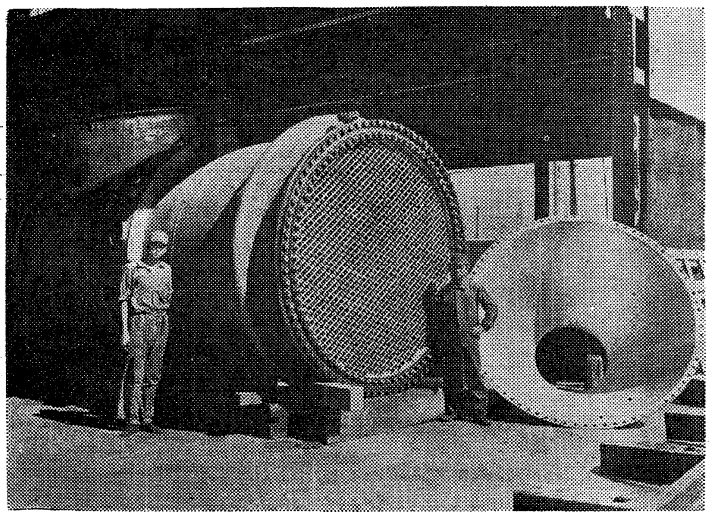

Photo. 7 アルミ製熱交換器

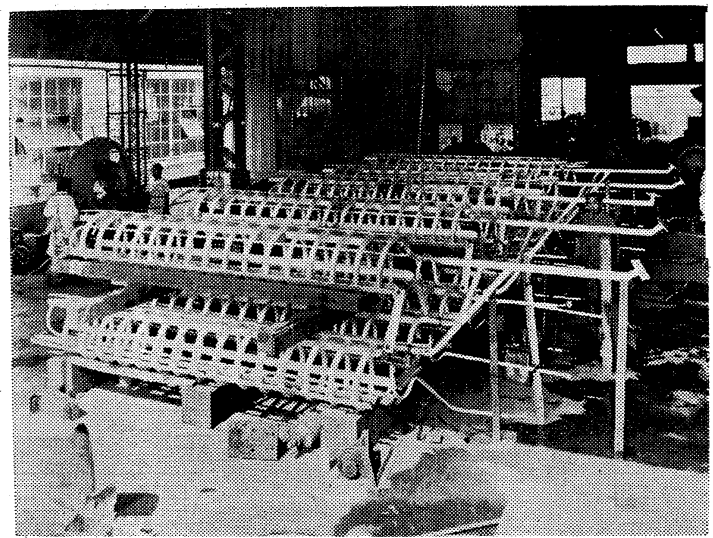

Photo. 8 染色用アルミニウム製コンデンサーの蛇管

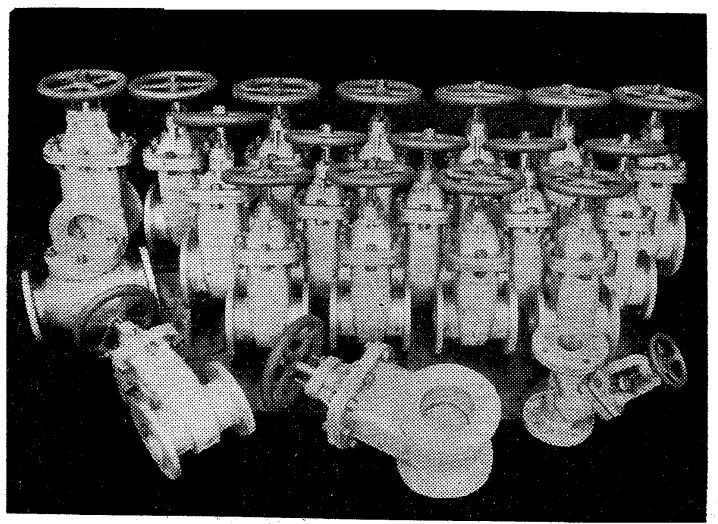

Photo.9 アルミニウム鉡物の仕切畣

ルブを造つた。畣座の接触部やスライド面が同じアルミ ニウムで焼付く欠点は、後日この部分をステンレスに置 き代えて優秀なものにしたという苦労が伝えられてい る。またシルミン製のストップバルブを多量に生産して いるが、このようなバルブ類を最も多量に生産したのは 昭和 11 年 3 月から 12 年 8 月頃であつた。

その他一以上の外 Photo. 10 の魚油製精用加圧釜を純 度 $99.5 \%$ 、厚さ $12 \mathrm{~m} / \mathrm{m}$ の板で造り（昭和 8 年）、また

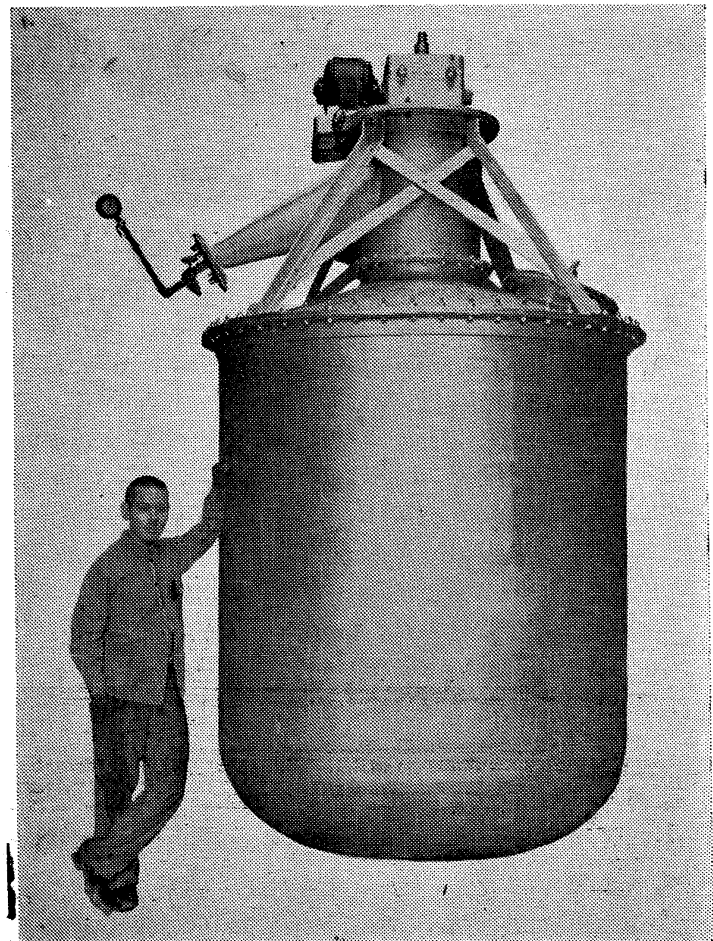

Photo. 10 魚油製精用加圧鉒

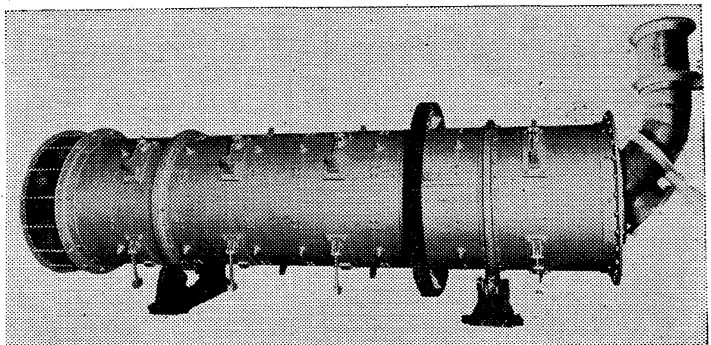

Photo. 11 硫安用ロータリー

Photo.11 のような内部にスクリユー・コンベヤのある 硫安用ロータリ一設備を純度 $99.8 \%$ の板から組立てた。

この外に各種各様の板金製品がある。その中から化学 工業や食品工業に関係あるものの名称を一括して次に挙 げる。

各種硝酸タンクー硝酸用ドラムカン $(150 l)$ 一ホル マリン容器一醋酸酸化機用冷却器一各種熱交換器— 各種蒸溜用冷却器一沪過器一オゾン発生器一硬化油 タンクー油釜一回転式二重釜一ラテックスタンクー ミルクキヤリヤ $(10,20,25 l)$ 一科量タンク $(2,000 l)$ 火薬箱一エヤタンク等

ただここで気のつくことは、これ等の板金製品はいず れも純アルミニウムで、合金は鋳物以外に使用していな いことである。これが戦前におけるこの種のものの特長 であつたといえよう。

いずれにしてもこのようなものの生産は昭和14年を境 にして翌年にはほとんど姿を没し、会社は航空機部品の 生産に移行してしまつた。したがつて戦後この種の生産 を開始するまでの約10年間は完全なブランクの時代を経 過する。

（未完） 